\title{
Pengembangan Modul Analisis Volumetri \\ Berbasis Standar Kompetensi Kerja Nasional Indonesia (SKKNI) pada LSP P1 Analis Kimia SMK-SMAK Makassar
}

\author{
The Development of Volumetry Analysis Module \\ Based on Indonesian National Work Competence Standards on LSP P1 \\ Chemical Analyst of SMK-SMAK Makassar
}

\author{
I Ketut Suryawirawan \\ Pascasarjana Universitas Negeri Makassar
}

\begin{abstract}
ABSTRAK
Tujuan penelitian ini adalah untuk mengetahui desain/alur kerja pengembangan modul melaksanakan analisis volumetri berbasis SKKNI, CBT dan pembelajaran mandiri dan untuk mengetahui kualitas modul yang telah dikembangan sampai pada hasil uji coba lapangan skala luas. Pegembangan modul melaksanakan analisis volumetri berbasis SKKNI di LSP P1 Analis Kimia SMK-SMAK Makassar berpedoman pada langkahlangkah pokok pengembangan Borg \& Gall (1983) yang dikombinasikan dengan langkah-langkah pengembangan modul yang terdapat dalam panduan Direktorat Jenderal Peningkatan Mutu Pendidik dan Tenaga Pendidik Kementerian Pendidikan. Modul yang dikembangkan yaitu: Panduan modul, Buku informasi, Buku Kerja dan Buku Penilaian. Ditinjau dari ketepatan cakupan isi, penggunaan bahasa, tampilan, sajian dan kelengkapan modul telah divalidasi oleh tiga orang ahli dan hasilnya valid dan reliabel. Berdasarkan uji validitas korelasi bivariate product moment dan uji reliabilitas koefisien Alpha Cronbach prestasi hasil belajar setelah mempelajari modul dengan software SPSS 22 diperoleh hasil modul melaksanakan analisis volumetri telah valid dan reliabel. Hasil uji coba oleh empat orang asesor atau 100\% dan 38 dari 40 atau 92,50\% peserta uji kompetensi memberikan respon positif mengenai penggunaan modul sebelum uji kompetensi, dengan demikian telah terpenuhi aspek kepraktisan. Tingkat ketuntasan belajar siswa diukur dari prestasi belajar kognitif dan psikomotorik setelah mempelajari modul sebesar 97,50\% telah memenuhi kriteria keefektifan.
\end{abstract}

Kata kunci: $S K K N I, C B T$, Valid dan Reliabel 


\begin{abstract}
The objectives of the research are to discover the design/workflow of volumetric analysis module based on SKKNI (Indonesian National Work Competence Standart), CBT, and independent learning to discover the quality of module developed until lerge scale field test result. The development of volumetric analysis module based on SKKNI in LSP P1 of Chemistry Analysis of SMK-SMAK Makassar is based on basic stages by Borg \& Gall's (1983) development stages combined with module development stages contained in Directorarate General of Educator and Teacher Quality Improvement of Education Minister guide. The module developed re: Module Guide, Information Book, Work Book and Assessment Book. In terms of content coverage accuracy, languange usange, display, course and completeness of the module had been validated by three experts and the result is valid and reliable. Based on validity test of bivariate product moment correlation and reliability test of Alpha Cronbach coefficient of learning result achievement and after studying the module with SPSS 22 software, it is obtained the result of volumetric analysis module is valid and reliable. The test result based on four assessor is $100 \%$ or 38 out of 40 or $92,50 \%$ of competency test give positive response on the untilization of module before competency test; therefore, practicality aspect had been fulfilled. The students' learning completeness levels measured from cognitive and psychomotor learning achievements after studying the module is $97,50 \%$ which had fulfilled effectiveness criteria
\end{abstract}

Keywords: SKKNI, CBT, valid and reliable

\section{PENDAHULUAN}

Salah satu standar dalam bidang kimia analisis yaitu SKKNI yang merupakan rumusan kemampuan kerja yang mencakup aspek pengetahuan, keterampilan, dan/atau keahlian serta sikap kerja yang relevan dengan pelaksanaan tugas dan syarat jabatan yang ditetapkan sesuai dengan ketentuan peraturan perundangundangan. Untuk mengetahui pemahaman pencari kerja teradap standar tersebut maka dilakukan sertifikasi kompetensi yaitu proses pemberian sertifikat kompetensi yang dilakukan secara sistematis dan objektif melalui uji kompetensi sesuai
SKKNI, Standar Internasional dan atau standar khusus yang telah ditetapkan. Penerapan SKKNI yang telah ditetapkan dilakukan oleh lembaga pendidikan vokasi industri berbasis kompetensi, lembaga pelatihan industri berbasis kompetensi, LSP, perusahaan industri dan/atau perusahan kawasan industri. Untuk jenis pekerjaan yang memiliki resiko tinggi teradap keamanan, keselamatan, kesehatan, dan lingkungan bagi tenaga kerja industri dan produk yang dihasilkan pemerintah menetapkan pemberlakuan SKKNI secara wajib artinya perusahaan industri dan/atau 
perusahan kawasan industri wajib menggunakan tenaga kerja indonesia yang memenuhi SKKNI.

Pemenuhan tenaga kerja industri yang memahami SKKNI, dapat dilakukan dengan sertifikasi kompetensi dimana hal ini dilakukan untuk mewujudkan kesesuaian antara sistem pengupahan dengan produktifitas kerja guna memberikan perlindungan dan kesejatraan bagi tenaga kerja indonesia. Sertifikasi kompetensi dilakukan oleh LSP yang telah memperoleh lisensi dari BNSP dimana LSP dapat dibentuk oleh asosiasi profesi, asosiasi industri, pelaku usaha industri, lembaga pendidikan, dan/atau lembaga pelatihan sesuai peraturan perundangundangan yang berlaku.

$$
\text { Lulusan SMK-SMAK }
$$

Makassar tahun ajaran 2015/2016 dengan masa tunggu 3 bulan setelah dinyatakan menyelesaikan studi terserap $76 \%$ pada dunia usaha dan industri yang tersebar di Indonesia, sesuai bidang keahliannya. Sekolah Menengah Kejuruan di lingkungan Pusdiklat Industri Kementerian Perindustrian bertujuan untuk menyiapkan calon tenaga kerja industri tingkat trampil yang kompeten dan berdaya saing untuk mewujudkan hal tersebut, maka pendidikan berbasis kompetensi, yang didukung dengan ketersediaan tenaga pengajar yang kompeten dan materi pembelajaran yang berbasis kompetensi.

$$
\text { Pendidikan berbasis }
$$

kompetensi mengarahkan peserta didik pada pencapaian kompetensi yang dipersyaratkan dalam pekerjaan. Pusdiklat Industri pada tahun 2014 telah melakukan penyusunan kurikulum pendidikan SMK yang berbasis kompetensi, yang ditindak lanjuti dengan penyusunan bahan ajar berbasis kompetensi, reposisi Pusdiklat jilid I dan II. Sebagai bagian dari sasaran yang akan dicapai dalam reposisi lembaga pendidikan SMKSMAK Makassar sebagai salah satu lembaga pendidikan yang berada dibawah Pusat Pendidikan dan Pelatihan Industri (Pusdiklat).

SMK-SMAK Makassar merupakan satu satunya sekolah negeri dikawasan timur Indonesia yang mengelola program keahlian Kimia Analisis empat tahun.Usaha yang telah dilakukan manajemen SMK-SMAK Makassar untuk mewujudkan visi, misi dan tujuan adalah dengan melakukan beberapa trobosan diantaranya adalah penerapan Sistem Manajemen Mutu (SMM) ISO 9001-2008 sejak tahun 2008, Akreditasi terbaik SMK Provinsi Sulawesi Selatan tahun 2011, kerja sama internasional dengan VAPRO Belanda dalam bidang sertifikasi Internasional HSE dan Kimia Analisis dan Pembentukan LSP dan dengan telah terbentuknya Lembaga Sertifikasi Profesi P1 Kimia Analisis (LSP-P1 Kimia Analisis) dan Tempat Uji Kompetensi (TUK) yang telah di akreditasi oleh BNSP.

Terbentuknya LSP dan TUK pada SMK-SMAK Makassar memberi peluang kepada lulusannya untuk memperoleh sertifikat kompetensi bidang kimia analisis disamping ijazah pendidikan formal pada umumnya. LSP P1 Analis kimia SMK-SMAK Makassar memiliki empat klaster SKKNI Kimia Analisis yang telah 
terakreditasi oleh BNSP yaitu: 1) Klaster Analisis Gravimetri; 2) Klaster Analisis Volumetri; 3) Klaster Analisis Spektrofotometri dan 4) Klaster Analisis Proksimat. Pada tahun 2014 LSP P1 Analis Kimia SMAK Makassar berhasil melakukan sertifikasi kompetensi teradap 40 lulusan SMAK Makassar sedangkan pada tahun 2015 telah melakukan asesmen teradap 127 calon lulusan SMAK Makassar, terjadi peningkatan yang singnifikan teradap jumlah yang diasesmen karena bertambahnya Asesor Kompetensi yang dimiliki oleh LSP P1 Analis Kimia SMAK Makassar.

Proses asesmen atau penilaian pada sertifikasi kompetensi berbeda dengan penilaian proses ujian akhir dan tengah semester, dimana pada sertifikasi kompetensi hanya dikenal istilah kompeten dan belum kompeten, arti kompeten yaitu peserta asesmen atau asesi telah memahami secara utuh klaster SKKNI yang diujikan baik pengetahuan, keterampilan maupun sikap kerja sedangkan jika belum kompeten adalah ada bagian yang belum dipahami. Penilaian ujian semester hal ini dapat dikonversi kedalam bentuk nilai, sehingga meskipun peserta asesmen belum memahami secara utuh dapat dinyatakan lulus dengan standar nilai kelulusan (KKM).

Dari data yang dimiliki LSP P1 Analis Kimia SMAK Makassar 87\% peserta asesmen sertifikasi profesi berhasil memperoleh sertifikat kompetensi dengan melakukan lebih dari satu kali proses asesmen artinya harus melakukan pengulangan, hal ini mungkin disebabkan oleh proses asesmen yang dilakukan pada tingkat/kelas empat padahal materi asesmen diperoleh pada saat mereka masih kelas satu, dua dan tiga, sehingga materi tersebut sudah tidak terlalu diingat lagi.

Klaster analisis volumetri yang mencakup kemampuan mempersiapkan larutan analisis, melaksanakan analisis volumetri serta melaporkan hasil analisis dalam satuan yang sesuai merupakan salah satu materi uji yang proses uji kompetensinya dilakukan di kelas empat, sementara peserta didik memperoleh materi tersebut pada kelas dua sehingga menjelang uji kompetensi perlu ada usaha yang dapat dilakukan oleh peserta didik untuk membangkitkan inggatan dan pemahamannya teradap klaster analisis volumetri yang akan diujikan, usaha itu adalah dengan pembelajaran mandiri, dan media yang paling sesuai untuk pembelajaran madiri adalah modul.

Berdasarkan kondisi tersebut
penulis mencoba melakukan pengembangan modul SKKNI pada klaster analisis volumetri yang di ujikan pada LSP P1 Analis Kimia SMAK Makassar. Pengembangan modul SKKNI ini menggunakan pendekatan kurikulum berbasis kompetensi yang biasa disebut CBT. Pendekatan CBT dipilih karena didalamnya telah terakomodasi penguasaan pengetahuan, keterampilan dan sikap kerja dan jika semuanya telah dipahami maka asesi/peserta uji kompetensi dapat dinyatakan kompeten. 
Melalui penelitian ini diharapkan dapat diperoleh gambaran pengembangan modul yang valid dan reliabilitas sesuaituntutan Sertifikasi Kompetensi oleh Lembaga Sertifikasi Kompetensi dan Kurikulum SMK/Pendidikan Vokasi berbasis kompetensi

\section{METODE PENELITIAN}

\section{A. Tahapan Pengembangan}

Penelitian pengembangan ini dilakukan untuk menghasilkan produk berupa modul pada unit kompetensi melaksanakan analisis volumetri dengan pendekatan Competensy Basic Traning (CBT) dan pembelajaran mandiri. Rancangan penelitian dan pengembangan ini mengacu pada standar SKKNI yang telah dimiliki oleh Lembaga Sertifikasi Profesi (LSP) P1 Analis Kimia SMK-SMAK Makassar dan telah dilakukan asesment pada Tempat Uji Kompetensi (TUK) Analis Kimia Makassar, dalam Sukmadinata (2008) secara lengkap menurut Borg dan Gall ada 10 langkah pelaksanaan strategi penelitian dan pengembangan, yaitu:

1. Penelitian dan pengumpulan data (Research and information collecting)

2. Perencanaan (Planing).

3. Pengembangan draf produk (Develop preliminary form of product)

4. Uji coba lapangan awal (Preliminary field testing)

5. Merevisi hasil uji coba (Main product revision)

6. Uji coba lapangan (Main field testing)
7. Penyempurnaan produk hasil uji lapangan (Operational product revision)

8. Uji Pelaksanaan lapangan (Operasional field testing)

9. Penyempurnaan produk akhir (Final product revision)

10. Diseminasi dan implementasi (Dissemination and implementation)

\section{B. Penilaian Produk}

Penilaian produk bertujuan untuk mendapatkan data yang akurat yang digunakan untuk melakukan revisi (perbaikan), menetapkan tujuan keefektifan, kevalidan, dan kepraktisan produk yang dihasilkan. Dalam penilaian produk ini diuraikan tentang desain penilaian, jenis data, instrumen pengumpulan data, dan teknik analisa data.

\section{Desaian Penilaian}

Tahap penilaian dari pengembangan ini melalui beberapa tahap berikut:

a. Tahap identifikasi masalah

\begin{tabular}{llr}
\multicolumn{2}{c}{ Peneliti } & \multicolumn{2}{c}{ mengidentifikasi } \\
masalah rill tentang & proses \\
pembelajaran & dan & sertifikasi
\end{tabular}
kompetensi yang tidak efektif karena kurangnya sumber belajar yang sesuai dengan standar uji SKKNI.

b. Tahap validasi ahli

Validasi ahli terdiri dari Ahli kimia analisis volumetri, ahli pendekatan CBT dan Pembelajaran mandiri, dan praktisi lapangan (guru kelas II) memberikan kritik dan saran teradap modul yang dihasilkan. 
Pengembangan Modul Analisis Volumetri Berbasis Standar Kompetensi Kerja Nasional Indonesia (SKKNI) pada LSP PI Analis Kimia SMK-SMAK Makassar

\section{Jenis Data}

$$
\text { Jenis data dalam }
$$

pengembangan modul ini adalah data kualitatif dan data kuantitatif. Data kualitatif berasal dari kritik, saran dan komentar dari para ahli teradap modul yang dikembangkan. Sedangkan pada uji coba lapangan, data kualitatif diperoleh dari observasi dan wawancara. Data kuantitatif diperoleh dari angket atau kuesioner yang diberikan kepada validator untuk menilai produk pengembangan modul dan tes hasil belajar pada modul/buku penilaian bagi asesi/peserta uji kompetensi yang digunakan untuk mengukur pencapaian peserta didik setelah mempelajari atau menggunakan produk pengembangan modul dalam rangka menghadapi uji kompetensi.

\section{Instrumen Pengumpulan Data}

Instrumen yang digunakan dalam pengembangan modul ini adalah observasi, wawancara, angket, dan tes. Observasi dilakukan pada saat penggunaan modul berlangsung mandiri dengan menggunakan kartu kontrol. Observasi dilakukan secara langsung untuk mengetahui kepraktisan dalam mempelajari modul hasil pengembangan. Angket dalam penelitian pengembangan modul ini diberikan pada validator untuk menilai produk pengembangan. Tes yang digunakan dalam pengembangan produk modul berbasis CBT dan pembelajaran mandiri ini adalah tes prestasi/sumatif dalam bentuk pilihan ganda dan essay yang terdapat dalam buku/modul penilaian pada akhir pembelajaran mandiri sebelum uji kompetensi dilakukan, yaitu tes yang digunakan untuk mengukur pencapaian seseorang setelah mempelajari sesuatu, sesuatu yang dimaksud adalah produk pengembangan modul berbasis CBT dan pembelajaran mandiri.

\section{Teknik Analisa Data}

Teknik analisa data yang digunakan dalam penelitian dan pengembangan ini adalah pengumpulan data lewat instrumen kemudian dikerjakan sesuai dengan prosedur penelitian dan pengembangan. Adapun data yang dianalisis dalam pengembangan modul berbasis CBT dan pembelajaran mandiri ini adalah data kuantitatif. Data kuantitatif diperoleh dari angket penilaian validator dan hasil tes kelas eksperimen.

$\begin{array}{ccr} & \text { Analisis statistik deskriptif } \\ \text { untuk } & \text { mendeskripsikan data }\end{array}$ kwantitatif dan memberikan makna terhadap deskripsi data tentang isi. Data yang dianalisis adalah data hasil validasi modul SKKNI berbasis CBT dan pembelajaran mandiri.

Analisis data yang diperoleh dikelompokkan menjadi 2 yaitu : (a) analisis validitas; dan (b) analisis reliabelitas. Selain melakukan validitas isi oleh pakar, dilakukan pula analisis validitas empirik dengan menggunakan rumus korelasi product moment yang dikemukakan oleh pearson. Untuk memutuskan apakah instrumen penilaian reliable, maka kriteria hasil dari ketiga validator minimal memiliki derajat keandalan yang "tinggi". Namun apa bila tidak demikian maka perlu dilakukan revisi 
berdasarkan saran yang diberikan oleh validator atau dengan melihat kembali aspek-aspek yang nilainya kurang untuk kemudian dilakukan validasi dan analisis ulang. Demikian seterusnya hingga dapat dinyatakan memiliki tingkat konsistensi internal yang ditentukan.

Penelitian pengembangan modul SKKNI berbasis CBT dan pembelajaran mandiri ini, peneliti menetapkan kriteria keefektifan dan kepraktisan sebagai berikut:

a. Ketuntasan belajar sekurangkurangnya $75 \%$ dari jumlah siswa telah kompeten pada akhir pembelajaran modul (tes sumatif), sebelum proses uji kompetensi pada LSP P1 Analis Kimia SMAK Makassar.

b. Tangapan positif dari rekan sejawat dan asesi/peserta uji kompetensi dalam menggunakan modul SKKNI berbasis CBT dalam proses pembelajaran.

\section{HASIL DAN PEMBAHASAN}

\section{A. Hasil Penelitian}

Pengembangan modul analisis volumetri mengacu pada penelitian pengembangan menurut Borg \& Gall (1983) yang dikombinasikan dengan panduan modul yang diterbitkan oleh Dirjen Peningkatan Mutu Pendidik dan Tenaga Kependidikan P4TK

Produk yang dihasilkan merupakan modul Melaksanakan Analisis Volumetri berbasis SKKNI yang telah memiliki struktur kelayakan modul. Berikut ini bagian-bagian modul meliputi :

\section{Buku panduan modul}

Dalam buku panduan modul mencakup acuan standar kompetensi kerja yaitu SKKNI KA.ANA.U.013.A Melaksanakan Analisis Volumetri yang mengandung unit kompetensi, deskripsi unit kompetensi, elemen kompetensi, kriteria unjuk kerja, batasan variabel, panduan penilaian, kompetensi kunci dan kemampuan yang harus dimiliki sebebelumnya/materi prasyarat.

Acuan standar kompetensi tersebut dikembangkan atau diturunkan dalam bentuk silabus pelatihan dengan pendekatan CBT, dimana kriteria unjuk kerja yang inggin dicapai dari setiap elemen kompetensi diterjemahkan dalam indikator unjuk kerja yang mencakup pengetahuan, keterampialan dan sikap kerja, dengan kata kerja dapat, mampu dan harus. Setiap indikator dilakukan identifikasi materi pembelajaran yang sesuai dengan tujuan pembelajaran yang inggin dicapai, dan dilakukan pemetaan waktu pembelajaran minimal untuk mencapai kompetensi tersebut.

\section{a. Buku Informasi}

Silabus pembelajaran yang telah dikembangkan pada buku informasi merupakan pengembangan dari materi pembelajaran pengetahuan yang terdapat dalam silabus pembelajaran. Secara umum tujuan yang diharapkan setelah mempelajari buku informasi pada modul melaksanakan analisis volumetri adalah peserta didik dapat memahami praktek laboratorium yang benar, dan memfasilitasi peserta didik sehingga 
pada akhir pelatihan diharapkan memiliki kemampuan melaksanakan analisis volumetri secara tepat yang meliputi kegiatan mempersiapkan larutan analisis, melakukan prosedur analisis, dan melaporkan hasil pengujian.

\section{b. Buku Kerja}

Buku kerja berisi petunjuk untuk pencapaian kompetensi pedagogik dan psikomotorik dalam bentuk tugas teori dan tugas praktek dalam mempersiakan larutan analisis, melakukan prosedur analisis dan melaporkan hasil pengujian. Pencapaian kompetensi dapat dilakukan melalui pemberian tugas teori dan tugas praktik. Untuk tugas teori biasanya dalam bentuk pertanyaan pilihan ganda maupun esai tertutup, adapaun tujuan dari pertanyaan tertutup tersebut adalah agar tidak menimbulkan persepsi yang berbeda -beda dari tiap peserta uji kompetensi yang mempelajari modul tersebut.

Tugas praktik digunakan untuk memantau perkembangan kompetensi psikomotorik peserta uji dengan pemberian tugas sesuai indikator unjuk kerja yang inggin dicapai, dengan memperhatikan kesehatan keselamatan kerja (K3), standar kinerja yang diharapkan dicapai setelah mempelajari kompetensi ini.

\section{c. Buku Penilaian}

Buku penilaian mengandung tiga unsur utama yaitu: lembar penilaian teori, lembar penilaian praktik dan lembar penilaian sikap kerja. Lebar penilaian teori pada umumnya untuk menilai penguasaan pengetahuan peserta pelatihan teradap unit kompetensi yang diujikan. Lembar penilaian praktik untuk menilai skill/keterampilan peserta pelatihan dalam menampilkan atau penguasaan tata urutan pelaksanaan praktek/demonstrasi pada setiap masing-masing tugas praktek. Lembar penilain praktek pada memuat hal berikut : Nama tugas praktek; Waktu; Tujuan; Daftar alat dan bahan; Indikator unjuk kerja keterampilan; Standar kerja; Instruksi Kerja; Hasil kerja dan Lembar pemeriksaan. Lembar penilaian sikap kerja dalam bentuk cek list atau daftar sikap yang menunjang keberhasilan pencapaian kompetensi yang diujikan bagi peserta pelatihan.

\section{Penggunaan Modul dengan Melaksanakan}

a. Evaluasi Formatif dan Sumatif

Pelaksanaan evaluasi formatif dilakukan dalam beberapa tahap yaitu:

1) Validasi oleh ahli

Modul pelatihan analisis volumetri berbasis SKKNI yang telah dikembangkan selanjutnya divalidasi oleh 3 ahli dengan cara memberikan kuesioner untuk diisi dan diskusi terbuka untuk membahas kualitas modul pelatihan yang dikembangkan, melalui beberapa kali perbaikan modul tersebut dinyatakan valid dan reliabel oleh ketiga ahli dengan beberapa revisi.

Hasil validasi dari para validator menunjukkan bahwa buku panduan modul yang terdiri atas standar kompetensi/SKKNI yang telah 
dikembangkan kedalam silabus pelatihan berbasis CBT memiliki kekurangan yaitu tidak ada batasan yang jelas antara indikator pada keterampilan dan sikap kerja, alokasi waktu belum ditentukan secara proporsional dan setelah melalui revisi buku panduan modul telah memenuhi kriteria penulisan sehingga dapat dilanjutkan untuk penyusunan buku informasi.

Hasil validasi tiga validator untuk buku informasi modul melaksanakan analisis volumetri berbasis SKKNI diantaranya adalah penulisan hendaknya selalua ada alinia baru, gambar yang terdapat dalam modul hendaknya berwarna dan jelas, sampul dibuat semenarik mungkin, sedangkan dilihat dari isi, sudah sesuai dengan kompetensi padagogik yang inggin dicapai.

Hasil validasi untuk buku kerja yang dilakukan oleh validator pada modul melaksanakan analisis volumetri berbasis SKKNI diantaranya adalah koreksi teradap beberapa soal dengan kesesuaiannya terhadap indikator unjuk kerja yang inggin dicapai soal tersebut, pertanyaan dari validator mengapa rata-rata soal esai yang dibuat adalah jenis tertutup. Soal -soal yang terdapat dalam buku kerja dibagi dalam beberapa tes formatif sesuai dengan jumlah elemen kompetensi yang terdapat dalam SKKNI yang dikembangkan, tes formatif terakhir akan digunakan pada penilaian prestasi belajar saat uji coba kelompok kecil. Dengan sedikit revisi buku kerja sudah siap untuk diuji cobakan.
Hasil validasi terhadap buku penilaian modul melaksanakan analisis volumetri berbasis SKKNI adalah pada bagian pengetikan soal, terdapat istilah atau singkatan yang tidak dijelaskan dalam bentuk keterangan misalnya $\mathrm{K}=$ Kompeten dan BK = Belom Kompeten, hal tersebut dianggap penting untuk menghindari persepsi yang berbeda antara asesor dan peserta uji kompetensi, buku penilaian ini digunakan pada penilaian prestasi belajar setelah mempelajari modul secara keseluruhan.

2) Evaluasi kelompok kecil/Uji coba lapangan kecil/tes formatif

Evaluasi kelompok kecil/uji coba lapangan kecil dilakukan pada minggu ketiga februari 2017 untuk kelompok B1 kelas IIB SMK-SMAK Makassar tahun ajaran 2016/2017 dengan jumlah siswa sebanyak 14 orang peserta didik, berdasarkan hasil prestasi belajar kognitif dan psikomotorik yang diolah dengan SPSS 22 diperoleh data dan dari hasil uji valid, nilai $r$ hitung untuk Pengetahuan (KI -3) dan Keterampilan (KI -4) yaitu $(0,334)$ lebih kecil dari nilai $r$ tabel $\mathrm{df}=12=0,5324 . \quad(0,334$ $<0,5324)$. Pada taraf signifikansi 0,05, maka dapat dikatakan Tidak Valid karena nilai $\mathrm{r}$ hitung lebih kecil dari $\mathrm{r}$ tabel.

Item dikatakan valid jika nilai $\mathrm{r}$ hitung $>$ dari nilai $\mathrm{r}$ tabelnya $r$ tabel dapat dilihat pada tabel $r$ statistik, dimana nilai $\mathrm{df}=\mathrm{N}-2$, disini saya menggunakan $\mathrm{N}=14$ dan jika mengikuti rumus maka $\mathrm{df}=\mathrm{N}$ (40) -2 $=12$. 
Nilai Cronbach'Alpha yang diperoleh dari analisis dengan program SPSS 22 sebesar 0.498 dan seretal dibandingkan dengan patokan nilai tersebut berada pada kategori alphoa < 0,50. Dari hasil uji reliabilitas, yang dilihat adalah nilai cronbach's alpha nilai cronbach's alpha yang kita peroleh sebesar 0,498, artinya tergolong reabilitas rendah.

Pada uji coba skala kecil ini peneliti juga diminta tanggapan siswa tentang modul melaksanakan analisis volumetri berbasis SKKNI yang mereka pelajari sebelum menjawab tes formatif, tanggapan siswa semua menyatakan tertarik terhadap modul tersebut ditinjau dari isi, bahasa, tampilan dan penyajiannya.

Keefektifan

modul

melaksanakan analisis volumetri sangat efektif karena pada uji coba skala kecil ini dapat dilihat dari capaian siswa yang keseluruhan nilainya berada diatas 75/cukup yaitu kriteria ketuntasan minimal pada kurikulum 2013.

Berdasarkan hasil evaluasi tersebut diatas, dengan beberapa perbaikan dan penyempurnaan maka dapat dilakukan uji coba lapangan dengan skala yang lebih besar.

3) Evaluasi kelompok besar/Uji pelaksanaan lapangan

Evaluasi lapangan atau Uji pelaksanaan lapangan dilakukan terhadap calon lulusan SMK-SMAK Makassar tahun ajaran 2016/2017 yang telah melaksanakan Praktek Kerja Industri (Prakerin) selam tiga bulan, uji kompetensi ini dilaksanakan pada awal maret 2017 dan yang memilih klaster melaksanakan analisis volumetri sebanyak 40 orang dengan 4 orang asesor. Sebelum melakukan uji kompetensi peserta uji kompetensi diberiikan modul sebagai pengganti SKKNI untuk dipelajari dan diakhiri dengan penilaian prestasi belajar baik padagogik maupun keterampilan. Adapun hasil evaluasi lapangan dapat dilihat pada Lampiran 8. Data tersebut diolah dengan program SPSS 22.

Dari hasil uji valid, nilai $r$ hitung untuk Pengetahuan (KI -3) dan Keterampilan (KI -4) yaitu $(0,670)$ lebih besar dari nilai $\mathrm{r}$ tabel $\mathrm{df}=38=$ 0,3120 . $\quad(0,670>0,3120)$. Pada taraf signifikansi 0,05, maka dapat dikatakan Valid karena ketentuannya adalah, item valid jika nilai $r$ hitung yang diperoleh lebih besar dibandingkan dengan $r$ tabel Item dikatakan valid jika nilai $\mathrm{r}$ hitung > dari nilai $\mathrm{r}$ tabelnya $r$ tabel dapat dilihat pada tabel $r$ statistik, dimana nilai $\mathrm{df}=\mathrm{N}-2$, disini saya menggunakan $\mathrm{N}=40$ dan jika mengikuti rumus maka $\mathrm{df}=\mathrm{N}$ (40) -2 $=38$. Jadi kita melihat nilai df $38=$ 0,3120, jika nilainya itemnya lebih besar dari 0,3120 maka item valid.

Nilai Cronbach'Alpha yang diperoleh dari analisis dengan program SPSS 22 sebesar 0.764 dan seretal dibandingkan dengan patokan nilai tersebut berada pada kategori alpha 0,70 - 0,90. Dari hasil uji reliabilitas, yang dilihat adalah nilai cronbach's alpha nilai cronbach's alpha yang kita peroleh sebesar 0,764, artinya tergolong reabilitas tinggi.

Data dan analisis diatas menunjukkan bahwa modul melaksanakan analisis volumetri yang 
dikembangkan dan di uji cobakan secara luas pada peserta uji kompetensi LSP P1 Analis Kimia SMK SMAK Makassar tahun anggaran 2017, dimana untuk klaster volumetri dengan jumlah asesi sebanyak 40 orang dimana modul yang dikembangkan telah valid dan reliabel.

\section{B. Pembahasan}

Hasil validasi dan uji coba/evaluasi modul melaksanakan analisis volumetri berbasis SKKNI digunakan untuk mengetahui kevalidan, keefektifan, dan kepraktisan modul yang telah dikembangkan.

\section{Kevalidan}

Suatu modul dikatakan valid apabila modul tersebut mampu mengevaluasi apa yang seharusnya dievaluasi. Modul yang telah dibuat sudah divalidasi oleh dua orang dosen pendidikan kimia FMIPA UNM dan seorang asesor kompetensi analisis volumetri dari LSP P1 Analis Kimia SMAK Makassar. Saran-saran yang diperoleh dari validator tersebut telah ditindaklanjuti dengan melakukan revisi, adapun jenis validasi yang dilakukan untuk menguji modul ini adalah validasi isi dan konstruk dimana dari analisis data dari validator dan tes hasil belajar modul kompetensi melaksanakan analisis volumetri berbasis SKKNI dinyatakan valid.

\section{Keefetifan}

Pada

modul yang dikembangkan ini keefektifannya dilihat dari tingkat keberhasilan yang dicapai peserta uji kompetensi dalam mencapai kriteria ketuntasan minimal yaitu sekurang-kurangnya $75 \%$ siswa telah kompeten dilihat dari prestasi hasil belajar pada akhir pembelajaran modul (tes sumatif dengan buku penilaian). Setelah melalui tahap uji coba lapangan jumlah peserta uji kompetensi yang berhasil memcapai kriteria ketuntasan minimal adalah 39 orang dari 40 peserta, dengan prosentase $97,50 \%$. berdasarkan data tersebut maka modul melaksanakan analisis volumetri yang dikembangkan dinyatakan efektif.

\section{Kepraktisan}

Suatu modul dikatakan praktis bila pelaksanaanya mudah dan dalam waktu yang relatif singkat. Pada modul pengembangan ini dilihat dari tangapan positif para pengguna modul yaitu peserta uji kompetensi dan asesor kompetensi, dimana jika lebih besar dari $70 \%$ memberi tanggapan positif terhadap manfaat, kemudahan, kepraktisan dalam mempelajari modul tersebut. Dalam penelitian ini setelah diminta tanggapan pengguna modul dengan memberikan kuesioner dan data dianalisis dengan stasistik deskriftif sebagian besar atau 92,50\% $\%$ peserta uji kompetensi dan $100 \%$ asesor memberikan tanggapan positif terhadap modul melaksanakan analisis volumetri yang dikembangkan.

\section{Temuan Khusus}

Berdasarkan analisis angket yang diberikan kepada asesor, peserta uji kompetensi dan pengamatan selama penelitian diperoleh temuan - temuan khusus pada penelitian pengembangan modul melaksanakan analisis volumetri berbasis SKKNI antara lain: 
a. Peserta uji kompetensi merasa sangat terbantu dalam memahami unit kompetensi/SKKNI sebelum melakukan uji kompetensi, hal ini terlihat dari respon positif peserta uji kompetensi dalam mempelajari modul, yakni sebesar $94 \%$.

b. Waktu yang digunakan untuk pembelajaran modul melaksanakan analisis volumetri berbasis SKKNI kurang terkontrol karena pembelajaran dilakukan diluar KBM, untuk mengatasi hal tersebut peneliti memberikan kartu kontrol dalam mempelajari modul.

c. Pada uji coba lapangan kecil hasil tes belajar kognitif dan psikomotorik tidak valid dan tingkat reliabelnya rendah, menurut peneliti hal ini disebabkan oleh jumlah soal yang diujikan kurang.

d. Penilain objektif dengan rubrik dan soal yang jelas. Sehingga nilai yang diperoleh peserta uji kompetensi bukan merupakan prediksi atau perkiraan.

e. Peserta uji kompetensi sangat terbantu dengan adanya modul melaksanakan analisis volumetri berbasis SKKNI karena memudahkan memahami informasi untuk persiapan uji kompetensi pada LSP P1 Analis Kimia SMKSMAK Makassar.

\section{Kendala selama penelitian}

Pelaksanaan uji coba modul melaksanakan analisis volumetri mengalami beberapa kendala, yaitu:

a. Menumbuhkan budaya pembelajarn mandiri bagi peserta uji kompetensi, kebiasaan peserta uji kompetensi masih seperti pada proses KBM dimana harus selalu dibimbing dan diarahkan secara terus menerus.

b. Penilaian dengan metode uji kompetensi membutuhkan waktu yang cukup lama, misalnya pada penilaian psikomotorik satu asesor hanya dapat menghadapi satu peserta uji kompetensi, agar semua aktifitas peserta uji dapat diamati dengan seksama.

\section{Keterbatasan Penelitian}

Penelitian pengembangan modul melaksanakan analisis volumetri berbasis SKKNI terdapat beberapa keterbatasan dalam pelaksanaan antara lain:

a. Tahapan uji coba skla kecil dan luas hanya dilakukan pasa LSP P1 Analis Kimia SMK-SMAK Makassar, hal ini disebabkan belum ada sekolah sejenis di Makassar atau Sulawesi Selatan yang mengajarkan unit kompetensi tersebut serta memiliki LSP.

b. Tahap Desiminasi dan Implementasi belum dilakukan karena terbatasnya waktu, biaya dan tempat penyebaran, dimana sekolah sejenis yang memiliki TUK dan LSP Analis Kimia hanya ada di Makassar, Bogor dan Padang.

c. Pilihan lain desiminasi adalah, peneliti merencanakan mengikuti seminar nasional, jurnal nasional dan penggunaan modul analisis volumetri hasil pengembangan pada setiap uji kompetensi di LSP P1 Analis Kimia SMK-SMAK Makassar. 


\section{KESIMPULAN DAN SARAN}

\section{A. Kesimpulan}

modul melaksanakan analisis volumetri berbasis SKKNI pada LSP P1 Analis Kimia SMK-SMAK Makassar adalah modifikasi dan adopsi dari model Borg \& Gall yang memiliki 10 langkah umum. Dalam pengembangan modul ini terdapat 6 langkah pengembangan modul Dirjen Peningkatan Mutu Pendidik dan Tenaga Kependidikan. Hasil analisis secara keseluruhan disimpulkan bahwa modul melaksanakan analisis volumetri yang telah dikembangkan memenuhi kriteria valid, reliabel, efektif dan praktis.

\section{B. Saran}

Berdasarkan hasil dan keterbatasan penelitian yang diperoleh dalam penelitian ini dikemukakan beberapa saran sebagai yaitu tahapan uji coba skala luas/lapangan kiranya dapat dilakukan lebih dari satu sekolah, Pada proses penelitian sebaiknya dilakukan control yang intensif terhadap peserta uji kompetensi dalam pembelajaran modul, Tahap diseminasi dan implementasi peneliti belum lakukan karena terbatasnya waktu dan biaya, peneliti merencanakan tahap ini dilakukan pada tiga LSP yang dimiliki oleh sekolah kejuruan yang sejenis yaitu SMAK Bogor, Padang dan Makassar.

\section{DAFTAR PUSTAKA}

Depdiknas.2008. Penulisan Modul. Jakarta: Dirjen Peningkatan Mutu Pendidik dan Tenaga Kependidikan.

Sukmadinata, Nana Syaodih. 2008. Metode Penelitian Pendidikan. Bandung: Remaja Rosdakarya. 